\title{
The chemistry, pharmacology, and toxicology of the biologically active constituents of the herb Hypericum perforatum $\mathrm{L}$.
}

\author{
Jiří Patočka
}

Military Medical Academy, Department of Toxicology, 50260 Hradec Králové and Department of Radiology, Faculty of Health and Social Care, University of South Bohemia, České Budějovice, Czech Republic

\begin{abstract}
Summary
St. John's wort (Hypericum perforatum) has been used as a medical herb for over 2000 years. Over the past two decades, its application as a standardized plant extract for treating depression has undergone rigorous scientific investigation, and its effectiveness has been shown in studies comparing it with other commonly used antidepressants and placebos. Safety and tolerability studies have revealed that Hypericum preparations have better safety and tolerability profiles than synthetic antidepressants. The indications for St. John's wort preparations are mild or moderate depression. The mechanism of the antidepressant action of Hypericum extract is not fully known. The view of the chemical composition and pharmaceutical a toxicological properties of biologically active substances of Hypericum perforatum is the main purpose of this paper.
\end{abstract}

Keywords: Hypericum perforatum - antidepressant - pharmacology - toxicology

\section{INTRODUCTION}

The species Hypericum perforatum $\mathrm{L}$. is a member of the family Guttiferae but some taxonimists classify the genus Hypericum in a separate family, Hypericaceae (Takhtajan 1973). The genus Hypericum consists almost of 400 species, of which ten morphologically and chemically distinct species grow in Central Europe. H. perforatum L. (Saint John's wort) is widely distributed all over the world. The crude drug, called herba hyperici, consists of the upper aerial parts of the plant collected just before or during the flowering period. The chemical constituents are exclusively accumulated in the flowers. The crude drug shows variation in the content of various constituents according to ecological factors, time of harvest and processing of the harvested plant material (Čellarová et al. 1994).

H. perforatum is a plant which has been used as a medicinal herb since ancient times. It is one of the medicinal plants which has traditionally been used in several European countries for the treatment of burns, skin injuries, and neuralgia. Recently, it has already gained a considerable international recognition and is now successfully competing for status as a standard antidepressant therapy. Over the past two decades, the pharmaceutical industry has made efforts to develop extracts of this drug, mostly standardized on the total content of the main constituents, in order to guarantee the high quality of the preparation. The best known standardized extract of herba hyperici is LI 160 (Lichtwer Pharma GmbH, Berlin, Germany) or ZE 117 (Max Zeller Söhne AG Herbal Remedies, Romanshorn, Switzerland), and many industrial preparations have been developed, such as Jarsin, Hyperforat, Psychotonin, Neuropas, etc. (Volz 1997).

Although the chemical and pharmaceutical properties of Hypericum extracts are well documented, very little is known about their molecular mode of action. The purpose of this paper is to review the biologically active constituents of the herb $H$. perforatum. These compounds are discussed with respect to their structural features, their concentration, biological activity, and their possible contribution to the clinically demonstrated antidepressant efficacy of extracts obtained from herba hyperici. 
BIOLOGICALLY ACTIVE COMPOUNDS OF Hypericum perforatum

Hydroalcoholic extracts, prepared from the upper parts of the plant with either $60 \%$ ethanol or $80 \%$ methanol $(\mathrm{v} / \mathrm{v})$ contain a spectrum of six major natural product groups: 1) naphthodianthrones, 2) phloroglucinols, 3) flavonoids, 4) biflavones, 5) phenylpropanes, and 6) proanthocyanidins. Additionaly, lesser amounts of tannins, xanthones, esential oils, and amino acids are present. All these compounds represent the main constituents in the dry crude drug of $H$. perforatum (Nahrstedt and Butteweck 1997).<smiles>Cc1cc(O)c2c(c1)Cc1cc(O)cc(O)c1C2=O</smiles>

I

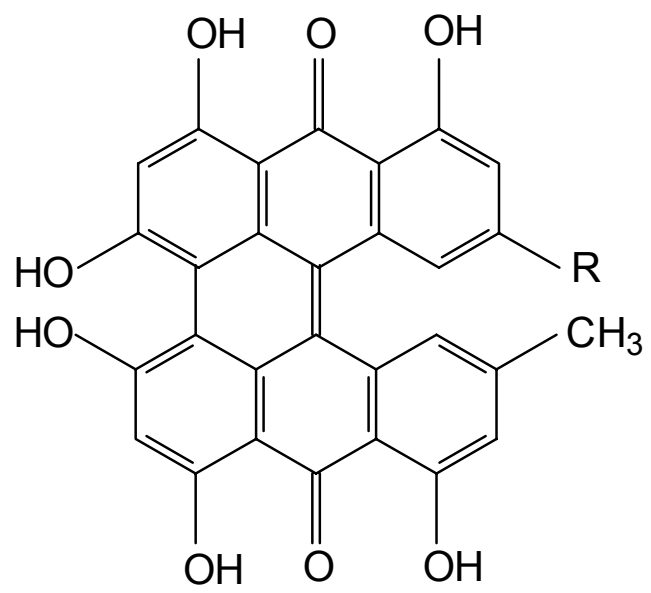

IIa $\mathrm{R}=\mathrm{CH}_{3}$

IIb $\mathrm{R}=\mathrm{CH}_{2} \mathrm{OH}$<smiles>[R]c1cc(O)c2c(=O)c3c(O)cc(O)c4c5c(O)cc(O)c6c(=O)c7c(O)cc(C)c8c1c2c(c34)c(c78)c65</smiles>

IIIa $\mathrm{R}=\mathrm{CH}_{3}$

IIIb $\mathrm{R}=\mathrm{CH}_{2} \mathrm{OH}$<smiles>O=c1c2c(O)cc3ccc4cc(O)c5c(=O)c6c(O)cc(O)c7c8c(O)cc(O)c1c1c2c3c4c5c6c7c81</smiles> 


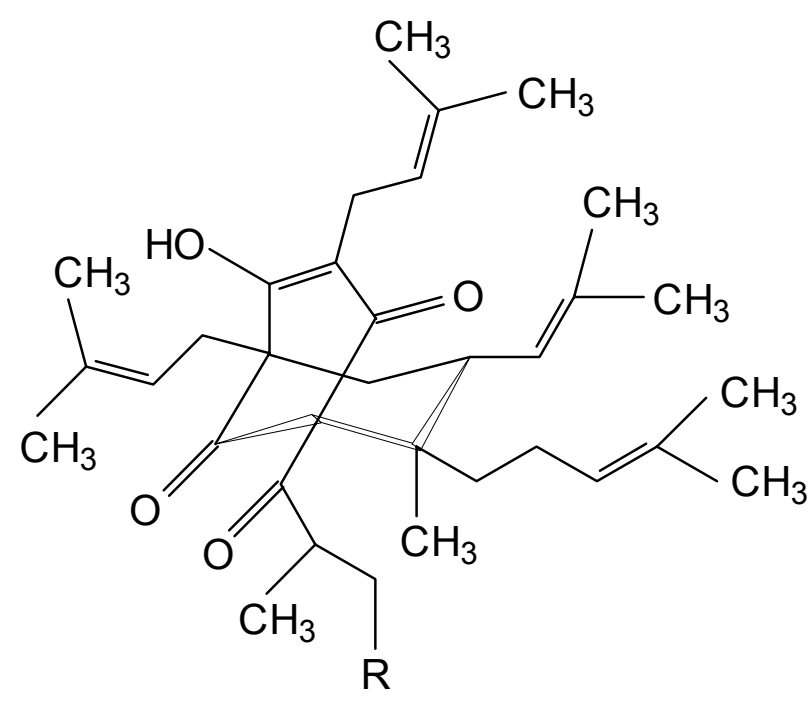

$\begin{array}{ll}\mathrm{Va} & \mathrm{R}=\mathrm{H} \\ \mathrm{Vb} & \mathrm{R}=\mathrm{CH}_{3}\end{array}$

\section{Naphthodianthrones}

These compounds are typical of the genus Hypericum (Hegnauer 1989) and at first mainly attracted phytochemists because of their intense red color and their phototoxic properties (Stock and Hoelzl 1991). Hypericins are derived from the metabolism of anthranoid compounds and probably emodinanthrone (I) may be the precursor of these structures (Brockmann 1957). Two so-called protoderivatives, protohypericin (IIa) and pseudoprotohypericin (IIb) were isolated from the plant but these unstable compounds are efficiently converted to the stable products, hypericin (IIIa) and pseudohypericin (IIIb) by the influence of light. Pseudohypericin is the main naphthodianthrone in $H$. perforatum and is usually present in 2 to 4 fold higher amounts than hypericin (Brantner et al. 1994). Afterwards cyclopseudohypericin (IV) was found as an oxidation product of pseudohypericin (Haeberlain et al. 1992). The chemical structures of all the naphthodianthones discussed are shown in Fig. 1.

Naphthodianthrones have restricted solubility in almost all solvents. Both hypericin and pseudohypericin are practically insoluble in water at ambient temperatures, but their solubility increases at higher temperatures (Niesel and Schilcher 1990), so that almost half of the amount present is extractable from the crude drug when preparing a tea with boiling water. Falk and Schmitzberger (1992) located water-soluble potassium salts of hypericin and/or pseudohypericin in some Hypericum species.
From a pharmacological point of view, the hypericins are the most interesting compounds of $H$. perforatum. A great many pharmacological effects have been described. Massive inhibition of monoamine oxidase A (MAO-A) can be shown with the total extract of $H$. perforatum (Thiede and Walper 1994). Using pure hypericin, no relevant inhibiting effects can be shown. From the results it can be concluded that the clinically proven antidepressive effect of hypericum extract cannot be explained in terms of MAO inhibition (Bladt and Wagner 1994).

Hypericin and pseudohypericin specifically inhibit protein kinase $\mathrm{C}$ with $\mathrm{IC}_{50}$ values of 1.7 $\mathrm{mg} /$ litre and $15 \mathrm{mg} /$ litre respectively, and show antiproliferative activity against mammalian cells. These data suggest that the antiretroviral activity of hypericin and pseudohypericin can be attributable to the inhibition of some phosphorylation influenced by protein kinase $\mathrm{C}$ during viral infection of cells (Takahashi et al. 1989). Hypericum extracts have only weak activity in assays related to the mechanisms of the synthetic antidepressants, that is, inhibition of MAO, catechol O-methyltransferase, or serotonin reuptake. It has been postulated that the clinical efficacy of hypericum extract could be attributed to the combined contribution of several mechanisms, each one too weak by itself to account for the overall effect (Bennet et al. 1998). The recent demonstration of a significant affinity of hypericin for sigma receptor binding is a novel finding and might contribute to a new understanding of the clinical attributes of $H$. perforatum (Raffa 1998). Although the pharmacology of hypericum extract is very well known, the mechanism of the antidepressant action of $H$. perforatum remains unknown.

Preliminary findings show that hypericin inhibited the DNA relaxation activity of topoisomerase IIalpha (EC 5.99.1.3) and led us to investigate the mechanism of enzyme inhibition. Rather than stabilizing the enzyme in covalent complexes with DNA (cleavage complexes), hypericin inhibited the enzyme prior to DNA cleavage. In vitro assays indicate that hypericin is a potent antagonist of cleavage complex stabilization by the chemotherapeutics etoposide and amsacrine. This antagonism appears to be due to the ability of hypericin to intercalate or distort DNA structure, thereby precluding topo II binding and/or DNA cleavage. In support of the view that it does not have harmful effects on DNA, the catalytic inhibition of topoisomerase IIalpha, hypericin was shown to be equitoxic to both wild-type and amsacrine-resistant HL-60 leukemia cell lines. Moreover, hypericin was incapable of stimulating DNA damage-responsive gene promoters that are activated by etoposide (Peebles et al. 2001). 
Hypericin is the major photosensitizing constituent of $H$. perforatum and is believed to cause hypericism. It has been proposed as a photosensitizer for photodynamic cancer therapy. Pseudohypericin, in contrast to hypericin, has no phototoxicity (Vandenbogaerde 1998). Phototoxic effects of hypericin have been observed in grazing animals after excessive ingestion of hypericincontaing plants and lethal reactions have been reported (Giese 1980). The phototoxicity of hypericin has been tested in humans by Brockmöller et al. (1997) on a group of healthy volunteers. Doses used in this study were higher than typical doses in current commercial preparations: from 2.81 to $11.25 \mathrm{mg}$ of total hypericin. In spite of these high doses, the frequency of phototoxic effect was equal to placebo medication and UV-light sensitivity was not increased.

\section{Phloroglucinols}

Phloroglucinol derivatives, likewise naphthodianthrones, are widely distributed in the genus Hypericum but also in other taxa such as the Rosaceae, Euphorbiaceae or Cannabidaceae. Two closely related compounds have been found in H. perforatum - hyperforin (Va) as the main phloroglucin compound and adhyperforin (Vb) contain one additional methyl group (Maisenbacher and Kovar 1992). Both compounds occur exclusively in the reproductive parts of the plant, in lesser amounts in flowers and in greater amounts in the ripe fruits. The total amount of both compounds increases from about $2 \% / 0.2 \%(\mathbf{V a} / \mathbf{V b})$ in the flowers to $4.4 \% / 1.8 \%$ in the ripe fruits. Standardized extracts are highly enriched in hyperforin (almost 40\%) (Chatterjee et al. 1998a). Hyperforins are lipophilic and unstable toward heat and light. Isoprenyl side chains of hyperforin and adhyperforin yield to oxidative degradation and 2-methyl-3-buten2 -ol is one of the products of their degradation. Another compound with the combined structure of hyperforin with a sesquiterpene of cadinan type has been isolated from the leaves of $H$. perforatum by Ruecker et al. (1995) at a yield of $0.0006 \%$. This unusual compound entitled hydroperoxycadiforin (VI) contains a hydroperoxo group in its molecule.

From a pharmacological standpoint the hyperforins are at present very interesting compounds of $H$. Perforatum, though their pharmacological activities are too little known.

Hyperforin itself was shown to inhibit or modulate several neurotransmitter systems in vitro. It is a potent uptake inhibitor of serotonin, dopamine, noradrenaline and GABA, with $\mathrm{IC}_{50}$ values of about $0.05-0.10 \mathrm{mg} / \mathrm{litre}$, and of L-glutamate about 0.5 $\mathrm{mg} /$ litre in synaptosomal preparations. It looks as though hyperforin is a possible major active principle responsible for the observed clinical efficacy of the extract as an antidepressant, and that it could also be a starting point for drug discovery projects engaged in the search for psychoactive drugs with novel modes of action (Chatterjee et al. 1998b). The mechanism of its antidepressant-like activity is currently considered to be the inhibition of synaptic reuptake of neurotransmitters

(Chatterjee et al. 2001). From this point of view hyperforin is a very interesting compound as the first member of a new class of compounds with a preclinical antidepressant profile due to a completely novel mechanism of action (Müller et al. 2001). Hyperforin has been demonstrated as a modulator of several neuronal ion channels, and inhibits smoothmuscle contraction induced by various neurotransmitters. Hyperforin (0.3-10 $\mathrm{mg} /$ litre) caused a concentration-dependent elevation of $\left[\mathrm{Ca}^{2+}\right]$ and extracellular acidification rate, and both of these effects are independent of extracellular $\mathrm{Ca}^{2+}$ (Koch and Chatterjee 2001).

The effect of Hypericum extract in therapeutic doses and hyperforin sodium salt were evaluated in rat and mouse avoidance tests. In a conditioned avoidance response test on rats, oral daily administration of hyperforin $(1.25 \mathrm{mg} / \mathrm{kg} /$ day $)$ or of the extract $(50 \mathrm{mg} / \mathrm{kg} /$ day $)$ before training sessions considerably improved learning ability from the second day onwards until day 7 . In addition, the memory of the learned responses acquired during 7 consecutive days of administration and training was largely retained even after 9 days without further treatment or training. The observations made using different doses indicate that these learningfacilitating and/or memory-consolidating effects by the agents follow inverse U-shaped dose-response curves in dose ranges lower than (for hyperforin) or equal to (for Hypericum extract) their effective dose in the behavioral despair test for antidepressants. In a passive avoidance response test on the mouse, a single oral dose $(1.25 \mathrm{mg} / \mathrm{kg})$ of hyperforin not only improved memory acquisition and consolidation, but also almost completely reversed scopolamineinduced amnesia. These observations suggest that the Hypericum extract could be a novel type of antidepressant with memory enhancing properties, and indicate that hyperforin is involved in its cognitive effects. Pure hyperforin seems to be a more potent antidementia agent than an antidepressant (Klusa et al. 2001). Recently hyperforin has been investigated very intensively as a novel antineoplastic agent (Schempp et al. 2002). 

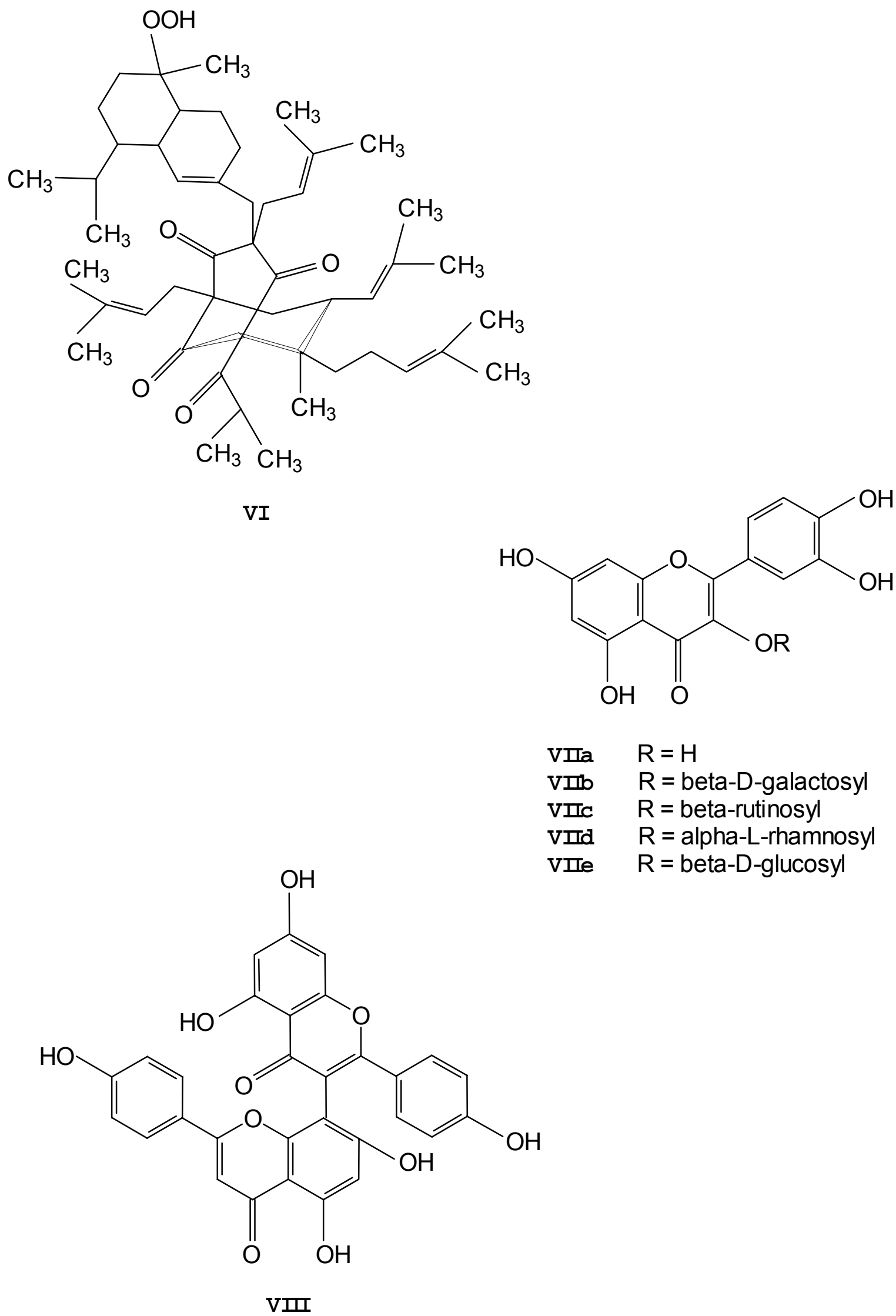


\section{Flavonoids}

These structures with quercetin (VIIa) as aglycone make up the major group of biologically active compounds in $H$. perforatum. Their content range 2-4\% and hyperoside (hyperin) (VIIb) and rutin (VIIc) usually dominate among the glycosides of $H$. perforatum followed by quercitrin (VIId) and isoquercitrin (VIIe) (Pietta et al. 2001). Flavonol glycosides possess spasmolytic activity (Morales and Lozoya 1994). In addition, they also inhibit monoamine oxidase $\mathrm{A}$ and catechol-Omethyltransferase enzyme (Thiede and Walper 1994) but the level of flavonoids present is too low to be responsible for the therapeutic efficacy of the crude Hypericum drug. Some flavonoids bind to the benzodiazepine receptor (Medina et al. 1997) and diverse authors argue that the flavonoids of Hypericum may act in the same way (Haeberlein et al. 1994, Viola et al. 1994). Flavonols present in plants as glycosides can be freed during fermentation and in the case of Hypericum flavonoids the quercetin is this phenolic compound.

Flavonols and flavonoids found in the edible portions of most food vegetables are thought to be genotoxic compounds (MacGregor 1986). Finally, quercetin has been reported to be carcinogenic (Poginski et al. 1988) but these results were based on positive Ames test with large doses of the flavonoid. Recent investigations suggest that there is little danger in consuming quercetin and similar derivatives (Stavric 1994, Rueff et al. 1986) and in contrast many authors consider quercetin to be an anticancer agent (Wall et al. 1990, Stavric 1994).<smiles>Oc1cc(O)c2c(c1)OC(c1ccc(O)c(O)c1)C(O)C2c1c(O)cc(O)c2c1OC(c1ccc(O)c(O)c1)C(O)C2</smiles>

$\mathrm{XI}$<smiles>O=c1cc(-c2ccc(O)c(-c3c(O)cc(O)c4c(=O)cc(-c5ccc(O)cc5)oc34)c2)oc2cc(O)cc(O)c12</smiles>

IX<smiles>O=C(O)C=Cc1ccc(O)c(O)c1</smiles>

$\mathrm{X}$<smiles>O=c1c2cc(O)c(O)cc2oc2cc(O)cc(O)c12</smiles>

XII 


\section{Biflavones}

Biflavones are a compatively uncommon group of dimeric flavones found rarely in some vegetable sources. Two compounds of this type, 3,8'biapigenin (VIII) and amentoflavone (IX), have been detected in $H$. perforatum in amounts of 0.1 to $0.5 \%$ and 0.01 to $0.05 \%$ (Berghoefer and Hoelzl 1987, 1989). Hitherto there are no data concerning the therapeutic significance of biflavones in $H$. perforatum. Nevertheless, recently amentoflavone was shown to bind in vitro to the brain benzodiazepine receptors (Baureithel et al. 1997), however, this compound does not penetrate through the blood-brain barrier (Nielsen et al. 1988). Certain biflavonoids including amentoflavone were previously reported to have an inhibitory effect on the group II phospholipase A2 activity. Amentoflavone was also found to inhibit cyclooxygenase from guinea-pig epidermis without affecting lipoxygenase. The anti-inflammatory and analgesic activities of the amentoflavone were also evaluated (Kim et al. 1998). When amentoflavone was administered intraperitoneally, it showed a potent anti-inflammatory activity as determined by amelioration of croton-oil induced mouse ear edema. It also showed potent anti-inflammatory activity in the rat carrageenan paw edema model $\left(E D_{50}=42 \mathrm{mg} / \mathrm{kg}\right)$ compared to the activity of prednisolone $(35 \mathrm{mg} / \mathrm{kg})$ and indomethacin (10 $\mathrm{mg} / \mathrm{kg}$ ). However, amentoflavone did not show significant inhibitory activity against rat adjuvantinduced arthritis, i.e. the chronic inflammatory model. In addition, amentoflavone was found to possess a potent analgesic activity in the acetic acid writhing test $\left(\mathrm{ED}_{50}=9.6 \mathrm{mg} / \mathrm{kg}\right)$ compared to the activity of indomethacin $(3.8 \mathrm{mg} / \mathrm{kg})$. All these results suggest that amentoflavone may be a potential model for a new type of anti-inflammatory agent having dual inhibitory activity of group II phospholipase A2 and cyclooxygenase.

\section{Phenylpropanes}

These compounds are mainly present in some plants as esters of hydroxycinnamic acids, such as pcoumaric acid and caffeic acid. Some of them are present in essential oils and have local anaesthetic activity (Ghelardini et al. 2001). In H. perforatum extract chlorogenic acid (X) has been detected, but its concentration is below $1 \%$ (Nahrstedt and Butterweck 1997) and its role in the pharmacological effects of Hypericum is unknown. The pharmacological effect of chlorogenic acid is very well known (Chassevent 1969). This polyphenolic compound, known to be present in significant amounts in coffee beans, was found to have a regressive effect on induced aberrant crypt foci (ACF), and preneoplastic lesions of the colon mucosa, as well as on the development of ACF in azoxymethane-induced colorectal carcinogenesis in rats (Mori et al. 2001). From other phenylpropanes an almost undetectable amount of caffeic acid has been found in $H$. perforatum (Nahrstedt and Butterweck 1997) as well as a lot of different polyphenolic compounds (Jurgenliemk and Nahrstedt 2002).

\section{Proanthocyanidins}

These compounds are present in the herb $H$. perforatum in the form of the tannin fraction which was found in the amount 6.2 to $12.1 \%$ of the crude drug. These compounds, measured by their conversion into red colored cyanidins, gave values from 2 to $4 \%$ and their concentration is highest at the pre-flowering stage (Brantner et al. 1994). The dimeric procyanidin B2 (XI) was isolated from the drug together with additional dimeric, trimeric, and tetrameric procyanidins (Melzer et al. 1991).

Proanthocyanidins exhibit many biological effects (Scholz 1994), including antioxidant (Bagchi et al. 2000), antiviral (De Bruine et al. 1999), antimicrobial (Scalbert 1991), vasoactive (Melzer et al. 1991) and others (Scalbert 2000), but no antidepressant effect has ever been reported.<smiles>COc1cc(C2Cc3c(OC)cc4c(=O)c5ccccc5oc4c3CC2CO)ccc1O</smiles>

XIII

\section{Other chemical constituents}

Other typical constituents are xanthones, which have been found in all parts of several Hypericum species (Benet and Lee 1989, Cardona 1990, Wu et al. 1998). H. perforatum contains 1,3,6,7tetrahydroxyxanthone (XII) and kielcorin C (XIII) 
at a concentration of about $0.01 \%$ (Nielsen and Arends 1993). Compound XI was investigated and found to inhibit monoamine oxidase A (Sparenberg et al. 1993) but its concentration in the drug is too low and cannot be responsible for the antidepressant activity.

In the structure of the leaves of $H$. perforatum are transparent secretory glands and reservoircavities that contain an essential oil that can be obtained from the dry herb by water steam distillation in amounts from 0.1 to $0.25 \%$ of the weight of the dry herb. This oil contains typical terpenes such as alpha-pinene and beta-pinene, limonene, myrcene and larger amounts of hydrocarbons and long chain alkanols and alcohols. In all 29 different compounds have been found in this oil (Roth 1990) and 2-methyloctane (16.4\%) and alpha-pinene $(10.6 \%)$ were the main constituents.

\section{CONCLUSIONS}

H. perforatum, a very well known plant, which has been used as a medicinal herb since ancient times, contains several natural products with noteworthy biological activity. The compounds that are responsible for the clinically demonstrated antidepressant effect of the plant drug are still not known, but at present the non-nitrogen compound hyperforin is regarded as the main carrier of antidepressant activity. Most of the compounds described in this report may be used for different purposes in the near future.

Received $3^{\text {rd }}$ June 2002.

Published online $26^{\text {th }}$ February 2003.

\section{REFERENCES}

Bagchi D., Bagchi M., Stohs S.J., Das D.K, Ray S.D., Kuszynski C.A., Joshi S.S, Pruess H.G.: Free radicals and grape seed proanthocyanidin extract: importance in human health and disease prevention. Toxicology 148: 187-197, 2000.

Baureithel K.H, Buter K.B., Engesser A., Burkard W, Schaffner W.: Inhibition of benzodiazepine binding in vitro by amentoflavone, a constituent of various species of Hypericum. Pharm. Acta Helv. 72: 153-157, 1997.

Bennet G.J., Lee H.H.: Xanthones from the Guttiferae. Phytochemistry 28: 967-998, 1989.

Bennett D.A. Jr, Phun L., Polk J.F., Voglino S.A., Zlotnik V., Raffa R.B.: Neuropharmacology of
St. John's Wort (Hypericum). Ann. Pharmacother. 32: 1201-1208, 1989.

Berghoefer R., Hoelzl J.: Biflavonoids in Hypericum perforatum; Part 1. Isolation of I3,II8-biapigenin. Planta Med. 53: 216-217, 1987.

Berghoefer R., Hoelzl J.: Isolation of I3',II8biapigenin (amentoflavone) from Hypericum perforatum. Planta Med. 55: 91, 1989.

Bladt S., Wagner H.: Inhibition of MAO by fractions and constituents of hypericum extract. J. Geriatr. Psychiatry Neurol. 7, Suppl 1: S5759, 1994.

Brantner A., Kartnig T., Quehenberger F.: Vergleichende phytochemische Untersuchungen an Hypericum perforatum L. und Hypericum maculatum Crantz. Scient. Pharm. 62: 261-276, 1994.

Brockman H.: Photodynamisch wirksame Pflanzenfarbstoffe. In: Zechmeister L.: Fortschr. Chem. Org. Naturstoffe, Bd. XIV, Springer Verlag, Wien 1957.

Brockmöller J., Reum T., Bauer S., Kerb R., Hübner W-D., Roots I.: Hypericin and pseudohypericin: Pharmacokinetics and effects on photosensitivity in humans. Pharmacopsychiatry 30, Suppl: 94-101, 1997.

Cardona L., Fernandez I., Pedro J.R., Serrano A.: Xanthones from Hypericum reflexum. Phytochemistry 29: 3003-3006, 1990.

Chatterjee S.S., Bhattacharya S.K., Wonnemann M., Singer A,. Muller W.E.: Hyperforin as a possible antidepressant component of hypericum extracts. Life Sci. 63: 499-510, 1998a.

Chassevent F.: Chlorogenic acid, physiological and pharmacological activity (Article in French) Ann. Nutr. Aliment. 23, Suppl 1: 1-14, 1969.

Chatterjee S.S., Biber A., Weibezahn C.: Stimulation of glutamate, aspartate and gammaaminobutyric acid release from synaptosomes by hyperforin. Pharmacopsychiatry 34, Suppl 1: S11-S19, 2001.

Chatterjee S.S., Noldner M., Koch E., Erdelmeier C.: Antidepressant activity of hypericum perforatum and hyperforin: the neglected possibility. Pharmacopsychiatry 31, Suppl. 1: 715, 1998b.

Čellarová E., Daxnerová Z., Kimaková K., Halusková J.: The variability of the hypericin contents in the regenerants of Hypericum perforatum. Act. Biotechnol. 14: 267-274, 1994.

De Bruyne T., Pieters L., Witvrouw M,. De Clercq E, Vanden Berghe D., Vlietinck A.J.: Biological evaluation of proanthocyanidin dimers and related polyphenols. J. Nat .Prod. 62: 954-958, 1999.

Falk H., Schmitzberger W.: On the nature of "soluble" hypericin in Hypericum species. Monatshefte Chem. 123:7 31-739, 1992. 
Ghelardini C., Galeotti N., Mazzanti G.: Local anaesthetic activity of monoterpenes and phenylpropanes of essential oils. Planta Med. 67: 564-566, 2001.

Giese A.: Hypericism. Photochem. Photobiol. Rev. 5: 229-255, 1980.

Haeberlain H., Tschiersch K-P., Schäfer H.L.: Flavonoids from Leptospermum scoparium with affinity to the benzodiazepine receptor characterized by structure activity relationships and in vivo studies of a plant extract. Pharmazie 49: 912-922, 1994.

Haeberlain H, Tschiersch K-P, Stock S, Hoelzl J: Johanniskraut (Hypericum perforatum L). Teil 1, Nachweis eines weiteren Naphthodianthrons. Pharm. Ztg. Wiss. 137: 169-174, 1992.

Hegnauer R.: Chemotaxonomie der Pflanzen, Vol. VII. Birkhäuser Verlag, Berlin 1989.

Jurgenliemk G., Nahrstedt A.: Phenolic compounds from Hypericum perforatum. Planta Med. 68: 88-91, 2002.

Kim H.K., Son K.H., Chang H.W., Kang S.S., Kim H.P: Amentoflavone, a plant biflavone: a new potential anti-inflammatory agent. Arch. Pharm. Res. 21: 406-410, 1998.

Klusa V., Germane S., Noldner M., Chatterjee S.S.: Hypericum extract and hyperforin: memoryenhancing properties in rodents. Pharmacopsychiatry, Suppl 1: S61-S69, 2001.

Koch E., Chatterjee S.S.: Hyperforin stimulates intracellular calcium mobilisation and enhances extracellular acidification in DDT1-MF2 smooth muscle cells. Pharmacopsychiatry 34, Suppl 1: S70-S73, 2001.

Maisenbacher P., Kovar K-A.: Adhyperforin: A homologue of hyperforin from Hypericum perforatum. Planta Med. 58: 291-293, 1992.

MacGregor J.T.: Genetic toxicology of dietary flavonoids. Prog. Clin. Biol. Res. 206: 33-43, 1986.

Medina J.H., Viola H., Wolfman C., Marder M., Wasowski C., Calvo D., Paladini A.C.:Overview - flavonoids: a new family of benzodiazepine receptor ligands. Neurochem. Res. 22: 419-425, 1997.

Melzer R., Fricke U., Holzl J.: Vasoactive properties of procyanidins from Hypericum perforatum L. in isolated porcine coronary arteries. Arzneim-Forsch /Drug Res. 41: 481483, 1991.

Morales M.A., Lozoya X.: Calcium-antagonist effects of quercetin on aortic smooth muscle. Planta Med. 60: 313-317, 1994.

Mori H., Kawabata K., Matsunaga K., Ushida J., Fujii K., Hara A., Tanaka T., Murai H.:

Chemopreventive effects of coffee bean and rice constituents on colorectal carcinogenesis. Biofactors 12: 101-105, 2000.
Müller W.E., Singer A., Wonnemann M.: Hyperforin - antidepressant activity by a novel mechanism of action. Pharmacopsychiatry 34, Suppl 1: S98-S102, 2001.

Nahrstedt A., Butterweck V.: Biologically active and other chemical constituents of the herb of Hypericum perforatum L. Pharmacopsychiatry 30, Suppl 2: 129-134, 1997.

Nielsen H., Arends P.: Structure of the xanthone lignoid kielcorin. Phytochemistry 17: 20402041, 1978.

Nielsen M., Frokjaer S., Braestrup C.: High affinity of the naturally-occuring biflavonoid, amentoflavon, to brain benzodiazepine receptors in vitro. Biochem. Pharmacol. 37: 3285-3287, 1988.

Niesel S., Schilcher H.: Vergleich der Freisetzung von Hypericin und Pseudohypericin in Abhängigkeit verschiedener Extraktionsbedingungen. Arch. Pharm. 323: 755, 1990.

Peebles K.A., Baker R.K., Kurz E.U., Schneider B.J., Kroll D.J.: Catalytic inhibition of human DNA topoisomerase IIalpha by hypericin, a naphthodianthrone from St. John's wort (Hypericum perforatum). Biochem. Pharmaco. 62: 1059-1070, 2001.

Pietta P., Gardana C., Pietta A.: Comparative evaluation of St. John's wort from different Italian regions. Farmaco 56 :491-496, 2001.

Poginski B., Westendorf J., Prosenc N., Kuppe M., Marquard H.: Johannis kraut (Hypericum perforatum L). Genotoxicität bedingt durch den Quercetingehalt. Dtsch. Apoth. Ztg. 128: 13641366, 1988.

Raffa R.B.: Screen of receptor and uptake-site activity of hypericin component of St. John's wort reveals sigma receptor binding. Life Sci. 62: PL265-PL270, 1988.

Rueff J., Laires A., Borba H., Chaveca T., Gomes M.I., Halpern M.: Genetic toxicology of flavonoids: the role of metabolic conditions in the induction of reverse mutation, SOS functions and sister-chromatid exchanges. Mutagenesis 1: 179-183, 1986.

Scalbert A.: Antimicrobial properties of tannins. Phytochemistry 30: 3875-3883, 1991.

Scalbert A., Deprez S., Mila I., Albrecht A.M., Huneau J.F., Rabot S.: Proanthocyanidins and human health: systemic effects and local effects in the gut. Biofactors. 13:1 15-120, 2000.

Schempp C.M., Kirkin V., Simon-Haarhaus B., Kersten A., Kiss J., Termeer C.C., Gilb B., Kaufmann T., Borner C., Sleeman J.P., Simon J.C.: Inhibition of tumour cell growth by hyperforin, a novel anticancer drug from St. John's wort that acts by induction of apoptosis. Oncogene 21: 1242-1250, 2002. 
Scholz E.: Pflanzliche Gerbstoffe. Dtsch. Apoth. Ztg. 134: 3167-3179, 1994.

Sparenberg B., Demisch B.L., Hoelzl J.: Untersuchungen über antidepressive Wirkstoffe von Johanniskraut. Phar. Ztg. Wiss. 6/138: 5054, 1993.

Stavric B.: Quercetin in our diet: From potent mutagen to probable anticarcinogen. Clin. Biochem. 27: 245-248, 1994.

Stock S., Hoelzl J.: Ist Johanniskraut phototoxisch? Med. Mod. Pharm. 14: 304-306, 1991.

Takahashi I., Nakanishi S., Kobayashi E., Nakano H., Suzuki K, Tamaoki T.: Hypericin and pseudohypericin specifically inhibit protein kinase C: possible relation to their antiretroviral activity. Biochem. Biophys. Res. Commun. 165: 207-1212, 1989.

Takhtajan A.: Evolution und Ausbreitung der Blütenpflanzen. G. Fischer, Stutgart 1973.

Thiede H.M., Walper A.: Inhibition of MAO and COMT by hypericum extracts and hypericin. J. Geriatr. Psychiatry. Neurol. 7, Suppl 1: S54S56, 1994.
Vandenbogaerde A.L,. Kamuhabwa A., Delaey E., Himpens B.E., Merlevede W.J., de Witte P.A.: Photocytotoxic effect of pseudohypericin versus hypericin. J. Photochem. Photobiol. B 45: 8794, 1998.

Viola H., Wolfman C., Destein M.L., Wasowski C., Pena C., Medina J.H., Paladini A.C.: Isolation of pharmacologically active benzodiazepine receptor ligands from Tilia tomentosa. J. Ethnopharmacol. 44: 47-53, 1994.

Volz H.P.: Controlled clinical trials of hypericum extracts in depressed patients - an overview. Pharmacopsychiatry.30, Suppl 2: 72-76, 1997.

Wall M.E, Wani M.C., Hughes TJ., Taylor H.: Plant antimutagens. In: Kuroda Y., Shankel D.B., Waters M.D.: Antimutagenesis and anticarconogenesis mechanism. II. Plenum Publ. Corp, New York 1990, p. 61-78.

Wu Q.L., Wang S.P., Du L.J., Yang J.S, Xiao PG: Xanthones from Hypericum japonicum and $\mathrm{H}$. henryi. Phytochemistry. 49:1395-1402, 1998.

\section{Address:}

Jiří Patočka, Department of Toxicology, Military Medical Academy, Šimkova 878, 50001 Hradec Králové, Czech Republic; patocka@pmfhk.cz 